\title{
24-Year course of patient with multiple intraperitoneal micro-aneurysms due to systemic lupus erythematosus
}

\author{
Takuzo Hano* \\ Wakayama Medical University, Satellite Clinic for Integrative and Anti-Aging Medicine, Japan
}

\begin{abstract}
Microaneurysms are a common finding in polyarteritis nodosa, but rare in systemic lupus erythematosus. The general prognosis for microaneurysms in systemic lupus erythematosus is not too bad, with only a few reported subarachnoid hemorrhages. We present the patient of a 46-year-old woman complicated with microaneurysm in systemic lupus erythematosus. She was admitted to our hospital because of hypertension and low-grade fever. Anti-ds-DNA antibody was positive and plasma renin activity was elevated markedly. Aortography demonstrated multiple microaneurysms and vascular stenosis in bilateral renal arteries. She was given a diagnosis of lupus vasculitis and was treated with steroids and cytotoxic agents. After administration of prednisolone, cyclophosphamide and angiotensin-converting enzyme inhibitor, low grade fever, anti DNA antibody and blood pressure were normalized. Although this angiographic finding has been considered specific for polyarteritis nodosa, it is suggested that it may be found in a variety of lupus vasculitis. Intraperitoneal microaneurysm was almost no changed in the follow up angiography. She developed subarachnoid hemorrhage in 24 years after onset.
\end{abstract}

\section{Introduction}

It has been considered that the angiographic findings of intraperitoneal microaneurysms is common in polyarteritis nodosa (PN). In contrast, intraperitoneal microaneurysm is rare in systemic lupus erythematosus4). Prognosis of microaneurysm in systemic lupus erythematosus is generally good. Several reports showed rupture of microaneurysm as subarachnoid hemorrhage of cerebral and spine [1-3]. A few reports of systemic lupus erythematosus showed renal infarction, but mechanism of vasculitis is not obscure [4-7]. We have experienced the female patient with renal infarction and intraperitoneal microaneurysms with a 24-year history of systemic lupus erythematosus (SLE). She was developed subarachnoid hemorrhage 24 years after onset.

\section{Case report}

Patient was pointed out hypertension first at 19 years old and revealed hypertension again at 9 months pregnancy at 21 years old. There was no abnormality in fetal growth and parturition. She visited outpatient clinic of our hospital for examination of hypertension at 23 years old. At a visit finding, she developed low grade fever and body weight loss for few weeks. She had no history. Her father had a systemic lupus erythematosus in family history. When she visited our hospital, she had high blood pressure (BP) of $146 / 112 \mathrm{mmHg}$ and a body temperature of $37.4^{\circ} \mathrm{C}$. On physical examination, there were buccal erythema and splenomegaly, but no sign was seen neurologically. Plasma renin activity (PRA) and serum aldosterone were $6.0 \mathrm{ng} / \mathrm{ml} / \mathrm{h}$ (normal range 0.2-3.9) and $370 \mathrm{pg} / \mathrm{ml}$ (normal range 30-159) at rest in the morning, respectively. White blood cell counts were decreased $\left(2.9 \times 10^{-9} / \mathrm{l}\right)$. CRP and ESR were slightly elevated, 0.66 (normal range $<0.40) \mathrm{mg} / \mathrm{dl}$ and $35 \mathrm{~mm} / \mathrm{h}$, respectively. Antinuclear antibody and anti-ds DNA antibody were weakly positive, $80 \mathrm{~T}$ and $37 \mathrm{IU} / \mathrm{ml}$ (ELISA), respectively. Anti-phospholipid antibody (ELISA), anti-Sm antibody (FEIA), anti-RNP antibody (CLEA), anti-SS DNA antibody (CLEA), anti-SS-B antibody (CLEA), and anti-neutrophil cytoplasmic autoantibodies (C-ANCA, P-ANCA) were negative (FEIA). Hepatitis $B$ virus antigen, anti-hepatitis $C$ virus antibody, and anti-HIV antibody were negative. Complement activity (CH50), $\mathrm{C} 3$ and $\mathrm{C} 4$ were decreased, 28.1 (normal range $<30.7$ ) U/ml, $61 \mathrm{mg} / \mathrm{l}$ and $13 \mathrm{mg} / \mathrm{l}$, respectively. Routine blood chemistry, urinalysis, urine sediments were normal except for a low serum potassium level $(3.6 \mathrm{mmol} / \mathrm{l})$. Plasma and urine fraction-free catecholamines and ACTH-cortisol were normal.

An abdominal CT showed left renal infarction and splenomegaly (Figure 1), but neither enlargement of adrenal glands nor an abnormal mass was seen. She underwent aortography, which revealed microaneurysms and vascular stenosis in peripheral branches in bilateral renal arteries, hepatic artery, superior mesenteric artery and inferior mesenteric artery (Figure 2). At the same time, PRA in both renal veins was checked, which were proven to be high bilaterally (right; 9.2 , left; $7.4 \mathrm{ng} / \mathrm{ml} / \mathrm{h}$, respectively). She was treated with temocapril to control hypertension. The patho-histlogical findings of buccal skin revealed no sign of vasculitis, but direct immnofluorescence test in the sun-protected crural skin demonstrated a positive lupus band test (LBT) $[8,9]$.

As these findings were fulfilled the American Rheumatism Association Criteria for SLE and positive LBT [3], she was given a diagnosis of lupus vasculitis and treated with steroids and cytotoxic agents (prednisolone $60 \mathrm{mg} / \mathrm{day}$, cyclophosphamide $50 \mathrm{mg} /$ day)

${ }^{*}$ Correspondence to: Takuzo Hano, Satellite Clinic for Integrative and AntiAging Medicine, Wakayama Medical University, Forte Wajima Bld. 5F, 2 chome1Ban, Honmachi 2-1, Wakayama, 640-8033, Japan, Tel: +81-73-488-1934; E-mail: nmaenza@nyit.edu

Key words: hypertension, systemic lupus erythematosus, microaneurysm, renal infarction, subarachnoid hemorrhage

Received: March 01, 2019; Accepted: March 14, 2019; Published: March 18, 2019 


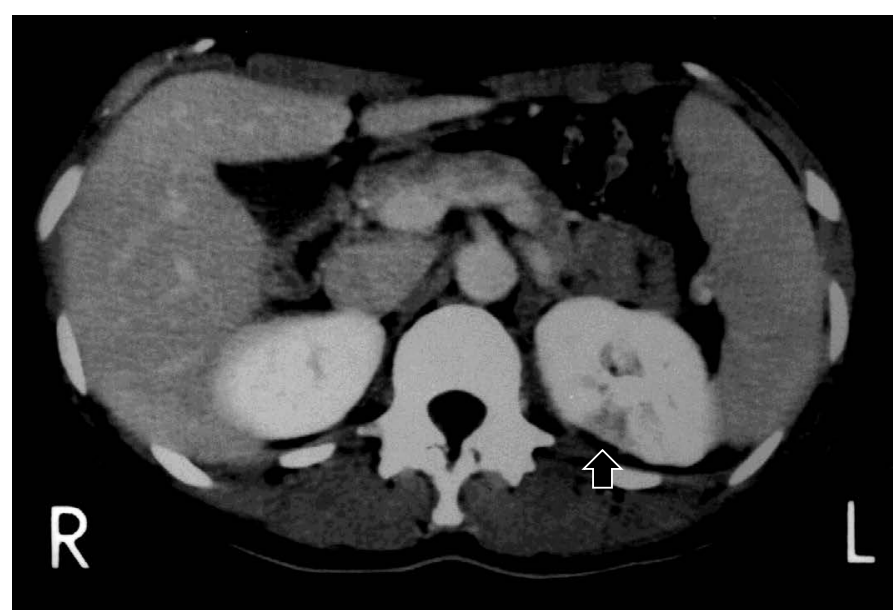

Figure 1. Location of renal infarction and splenomegaly in abdominal computed tomographic scan at 24-years old

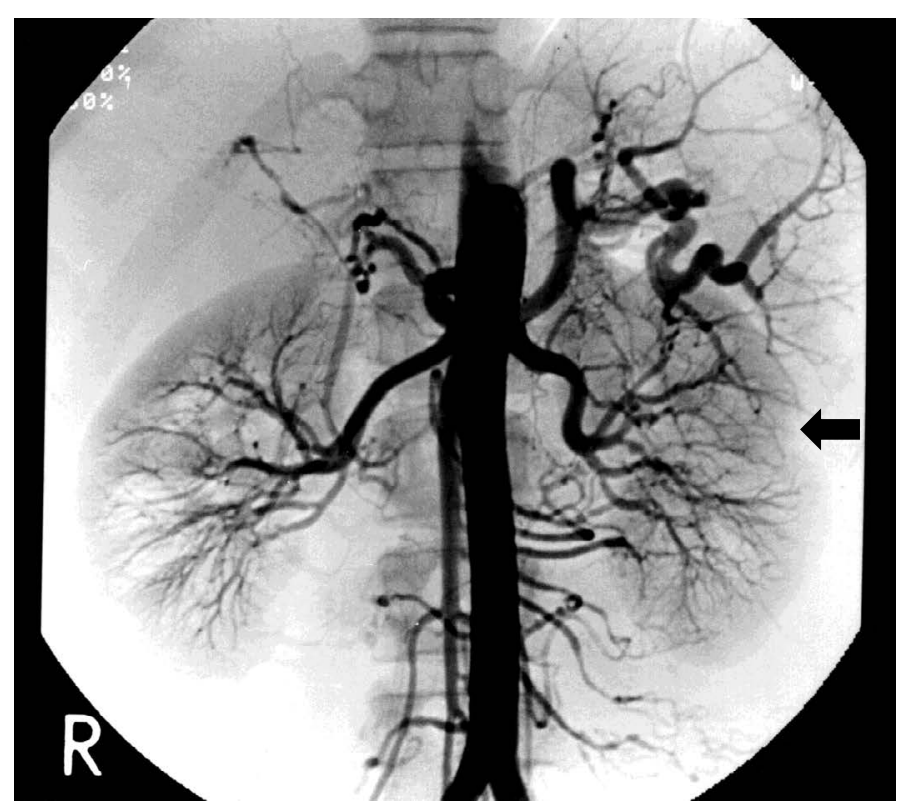

Figure 2. Aortography at 24-years old demonstrating microaneurysms and vascular stenosis in renal arteries, hepatic artery, superior mesenteric artery and inferior mesenteric artery

according to guideline. After treatment, low grade fever, anti-DNA, CH50 and BP were gradually, normalized (Table 1). The 16th hospital week, she was discharged from our hospital with prednisolone $20 \mathrm{mg} /$ day, cyclophosphamide $50 \mathrm{mg} /$ day and temocapril $2.0 \mathrm{mg} /$ day. She received angiography 2 and 6 years later and findings of intraperitoneal microaneurysm was no changed. We changed drugs to prednisolone $10 \mathrm{mg} /$ day and temocapril $4.0 \mathrm{mg} /$ day lyear after treatment. Level of $\mathrm{CH} 50, \mathrm{C} 3$ and $\mathrm{C} 4$ was kept in normal range after that. Twentyfour years later she developed a subarachnoid hemorrhage. Cerebral angiography revealed each one microaneurysm in left and right middle cerebral artery.

\section{Discussion}

As present case was young female with hypertension, secondary hypertension like as renal or renovascular hypertension was examined. In the first step of basic examination, blood chemistry, PRA, PAC and radiographic examination was carried out to rule out of secondary hypertension. PRA showed extremely high level and renal infarction was fined out in computer tomography. So, we added angiographic study and specific antigen test to determine the vascular lesion and its cause. A microaneurysym is characteristic clinical picture of PN. In this patient, although anti-Sm antigen was negative, anti-ds DNA antibody was positive and white blood cells were decreased. These results did not fully support SLE [10]. SLE was diagnosed finally by showing LBT positive findings by skin biopsy. Intraperitoneal renal aneurysms have been encountered not only in PN but also in such diseases as arterial hypertension, rheumatoid arthritis, primary biliary cirrhosis, diabetes mellitus, renal carcinoma, fibromuscular dysplasia, temporal arteritis, and SLE [11-14]. Clinical evidence of arterial disease in SLE patients varies considerably from patients to patients. It is an established fact that systemic vasculitis can occur during SLE as other rheumatic diseases, but angiographically demonstrable intraperitoneal renal aneurysm is rare [11]. The pathogenesis of this rare, true inflammatory vasculitis resembling PN may involve mechanisms like those proposed for vasculitis of the PN type [15].

The fact that intramural immune deposits have not yet been found in these lesions and that they may occur in association with the benign mesangial pattern of lupus nephritis makes a role for immune complex deposition unlikely [7].

The initial symptom of this case was renal infarction. Renal infarction was shown postpartum lupus vasculitis in several previous reports [16] and present case was also postpartum infarction. And, previous several cases of renal infarction were combined with an antiphospholipid syndrome [4-6], but present case showed negative antiphospholipid titer. Previous reports showed that complications of subarachnoid hemorrhage are very rare, but the recent whole-body search of SLE showed that the relative risk in SLE was $3.85[1,2]$. The relative risk of stroke was high among individuals under 50 years of age [1]. SAH of Japanese SLE patients occurred more frequently in Western European countries [3]. The present case developed subarachnoid hemorrhage at 46-year old.

Regarding systemic vascular lesions of SLE, the prognosis of patients with vascular lesions of middle arteries and thrombosis is the

Table 1. Blood chemistry at 46-year old

\begin{tabular}{|c|c|c|c|}
\hline WBC & $5100 / \mathrm{ml}$ & T.Chol & $210 \mathrm{mg} / \mathrm{dl}$ \\
\hline RBC & $473 \times 104 / \mathrm{ml}$ & HDL-C & $81 \mathrm{mg} / \mathrm{dl}$ \\
\hline $\mathrm{Hb}$ & $14.7 \mathrm{~g} / \mathrm{dl}$ & LDL-C & $133 \mathrm{mg} / \mathrm{dl}$ \\
\hline $\mathrm{Ht}$ & $44.2 \%$ & TG & $140 \mathrm{mg} / \mathrm{dl}$ \\
\hline Plt & $20.5 \times 104 / \mathrm{ml}$ & UA & $5.8 \mathrm{mg} / \mathrm{dl}$ \\
\hline Neutr & $53.1 \%$ & BUN & $15.3 \mathrm{mg} / \mathrm{dl}$ \\
\hline Lymph & $38.2 \%$ & $\mathrm{Cr}$ & $0.59 \mathrm{mg} / \mathrm{dl}$ \\
\hline Mono & $6.5 \%$ & $\mathrm{Na}$ & $138 \mathrm{mEq} / 1$ \\
\hline Eosino & $2.0 \%$ & $\mathrm{~K}$ & $4.0 \mathrm{mEq} / 1$ \\
\hline Baso & $0.2 \%$ & $\mathrm{Cl}$ & $101 \mathrm{mEq} / 1$ \\
\hline BS & $122 \mathrm{mg} / \mathrm{dl}$ & $\mathrm{CRP}$ & $0.13 \mathrm{mg} / \mathrm{dl}$ \\
\hline HbA1c & $5.9 \%$ & ACTH & $5.6 \mathrm{pg} / \mathrm{ml}$ \\
\hline T.Prot & $7.0 \mathrm{~g} / \mathrm{dl}$ & Cortisol & $13.4 \mathrm{mg} / \mathrm{dl}$ \\
\hline Alb & $3.7 \mathrm{~g} / \mathrm{dl}$ & PRA & $6.2 \mathrm{ng} / \mathrm{ml} / \mathrm{h}$ \\
\hline T.Bil & $0.7 \mathrm{mg} / \mathrm{dl}$ & PAC & $74.7 \mathrm{pg} / \mathrm{ml}$ \\
\hline D.Bil & $0.2 \mathrm{mg} / \mathrm{dl}$ & CH50 & $39 \mathrm{CH} 50 / \mathrm{ml}$ \\
\hline AST & $21 \mathrm{U} / 1$ & anti-ss-DNA Ab & $15.7 \mathrm{AU} / \mathrm{ml}$ \\
\hline ALT & $24 \mathrm{U} / 1$ & anti-ds-DNA-Ab & $4.2 \mathrm{IU} / \mathrm{ml}$ \\
\hline ALP & $364 \mathrm{U} / 1$ & Urine & - \\
\hline LDH & $195 \mathrm{U} / 1$ & Prot & - \\
\hline g-GT & $43 \mathrm{U} / 1$ & Sugar & - \\
\hline ChE & $380 \mathrm{U} / 1$ & Urob & - \\
\hline CPK & $76 \mathrm{U} / 1$ & pH & 6.0 \\
\hline & & & \\
\hline & & & - \\
\hline
\end{tabular}


most important [17]. Certain clinical symptoms, etiology, etiology, and outcome affect treatment strategies. Previous report showed incidence of SAH of Japanese SLE patients was 1 to $3.9 \%[18,19]$. Most cases of subarachnoid hemorrhage were shown in discontinue of steroid therapy and active SLE [19]. Although this patient continues steroid therapy, subarachnoid hemorrhage was developed. So strict follow-up observation is necessary for cerebral blood vessels in SLE patients.

\section{Conclusion}

We experienced rare young female case of intraperitoneal microaneurysm in SLE. First sign of this patient was hypertension, slight fever and weight loss. Renal infarction was the key to clarify the lupus vasculitis. Microaneurysm in SLE was reported to be good prognosis but this case developed arachnoid hemorrhage 24 years after onset. Strict follow-up examination is needed to prevent a stroke due to rupture of microaneurysm.

\section{References}

1. Holmqvist M, Simard JF, Asplund K, Arkema EV (2015) Stroke in systemic lupus erythematosus: a meta-analysis of population-based cohort studies. RMD Open 1: e000168. 1. [Crossref]

2. Torne R, Rodriguez-Hernandez A, Bernard T, Arikan Abello F, Vilalta Castan J, et al. (2015) Subarachnoid hemorrhage in systemic lupus erythematosus: systematic review and report of three cases. Clin Neurol Neurosurg 128: 17-24. [Crossref]

3. Owada T, Takahashi K, Kita Y (2009) Subarachnoid hemorrhage in systemic lupus erythematosus in Japan: two case reports and a review of the literature. Mod Rheumatol 19: 573-80. [Crossref]

4. Padilla-Fernandez B, Garcia-Casado D, Martin-Izquierdo M, Manzano-Rodriguez C, Garcia-Garcia J, et al. (2013) Bilateral renal infarction in a lupus patient: an unusual pathology. Clin Med Insights Case Rep 6: 87-91. [Crossref]

5. Kuzmanovska DB, Sahpazova EM, Grujovska SJ, Trajkovski Z (2004) Renal infarction in a child with systemic lupus erythematosus. Pediatr Nephrol 19: 685-687. [Crossref]

6. Suwabe H, Moriuchi J, Hoshina Y, Iwata Y, Ichikawa Y, et al. (1993) Renal and cerebral infarctions in a patient with systemic lupus erythematosus without antiphospholipid antibodies. Ryumachi 33: 335-340. [Crossref]
7. Appel GB, Silva FG, Pirani CL, Meltzer JI, Estes D (1978) Renal involvement in systemic lupus erythematosus (SLE). A study of 56 patients emphasizing histologic classification. Medicine 57: 371-410. [Crossref]

8. Burnham TK, Neblett TR, Fine G (1963) The application of the fluorescent antibody technique to the investigation of lupus erythematosus and various dermatoses. $J$ Invest Dermatol 41: 451-456. [Crossref]

9. George R, Kurian S, Jacob M, Thomas K (1995) Diagnostic evaluation of the lupus band test in discoid and systemic lupus erythematosus. Int J Dermatol 34: 170-173. [Crossref]

10. Tan EM, Cohen AS, Fries JF, Masi AT, McShane DJ, et al. (1982) The 1982 revised criteria for the classification of systemic lupus erythematosus. Arthritis Rheum 25 : 1271-1277. [Crossref]

11. Longstreth PL, Korobkin M, Palubinskas AJ (1974) Renal microaneurysms in a patient with systemic lupus erythematosus. Radiology 113: 65-66. [Crossref]

12. O'Neill WM Jr, Hammar SP, Bloomer A (1976) Giant cell arteritis with visceral angiitis. Arch Intern Med 136: 1157-1160. [Crossref]

13. Easterbrook JS (1980) Renal and hepatic microaneurysms. Report of a new entity simulating polyarteritis nodosa. Radiology 137: 629-630. [Crossref]

14. Hekali P, Kajander H, Pajari R, Stenman S, Somer T, et al. (1991) Diagnostic significance of angiographically observed visceral aneurysms with regard to polyarteritis nodosa. Acta Radiol 32: 143-148. [Crossref]

15. D'Agati V, Appel GB (1994) Polyarteritis nodosa, Wegener's granulomatosis, Churg-Strauss syndrome, temporal arteritis, Takayasu arteritis, and lymphomatoid granulomatosis. In: Renal Pathology with Clinical and Functional Correlations, 2nd Ed., Tisher C, Brenner B, Eds., JB Lippincott Co., Philadelphia, p.1087-1153.

16. Varalaxmi B, Sandeep P, Sridhar AV, Raveendra P, Kishore CK, et al. (2015) Renal infarction due to lupus vasculopathy. Lupus 24: 985-989. [Crossref]

17. Hashimoto H, Maekawa S, Nasu H, Okada T, Shiokawa Y, et al. (1984) Systemic vascular lesions and prognosis in systemic lupus erythematosus. Scand J Rheum 13: 45-55. [Crossref]

18. Baizabal Carvallo JF, Cantu Brito C, Estanol B, Garcia Ramos GS (2007) Subarachnoid hemorrhage as a complication of systemic lupus erythematosus. Cerebrovasc Dis 24 301-304. [Crossref]

19. Mimori A, Suzuki T, Hashimoto M, Nara H, Yoshio T, et al. (2000) Subarachnoid hemorrhage and systemic lupus erythematosus. Lupus 9: 521-526. [Crossref]

Copyright: (C2019 Hano T. This is an open-access article distributed under the terms of the Creative Commons Attribution License, which permits unrestricted use, distribution, and reproduction in any medium, provided the original author and source are credited. 